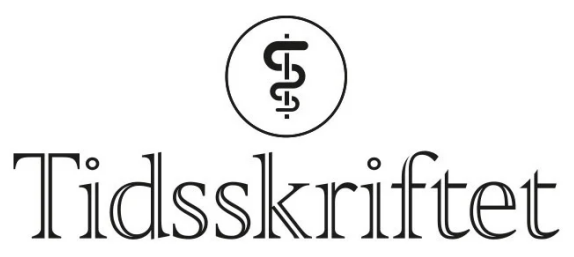

DEN NORSKE LEGEFORENING

\title{
Bypassoperasjon eller PCI-behandling ved trekarssykdom?
}

FRA ANDRE TIDSSKRIFTER

TORBJØRN ØYGARD SKODVIN

Tidsskriftet

Bypassoperasjon er bedre enn perkutan koronar intervensjon ved stenose i tre koronarkar, viser randomisert studie.

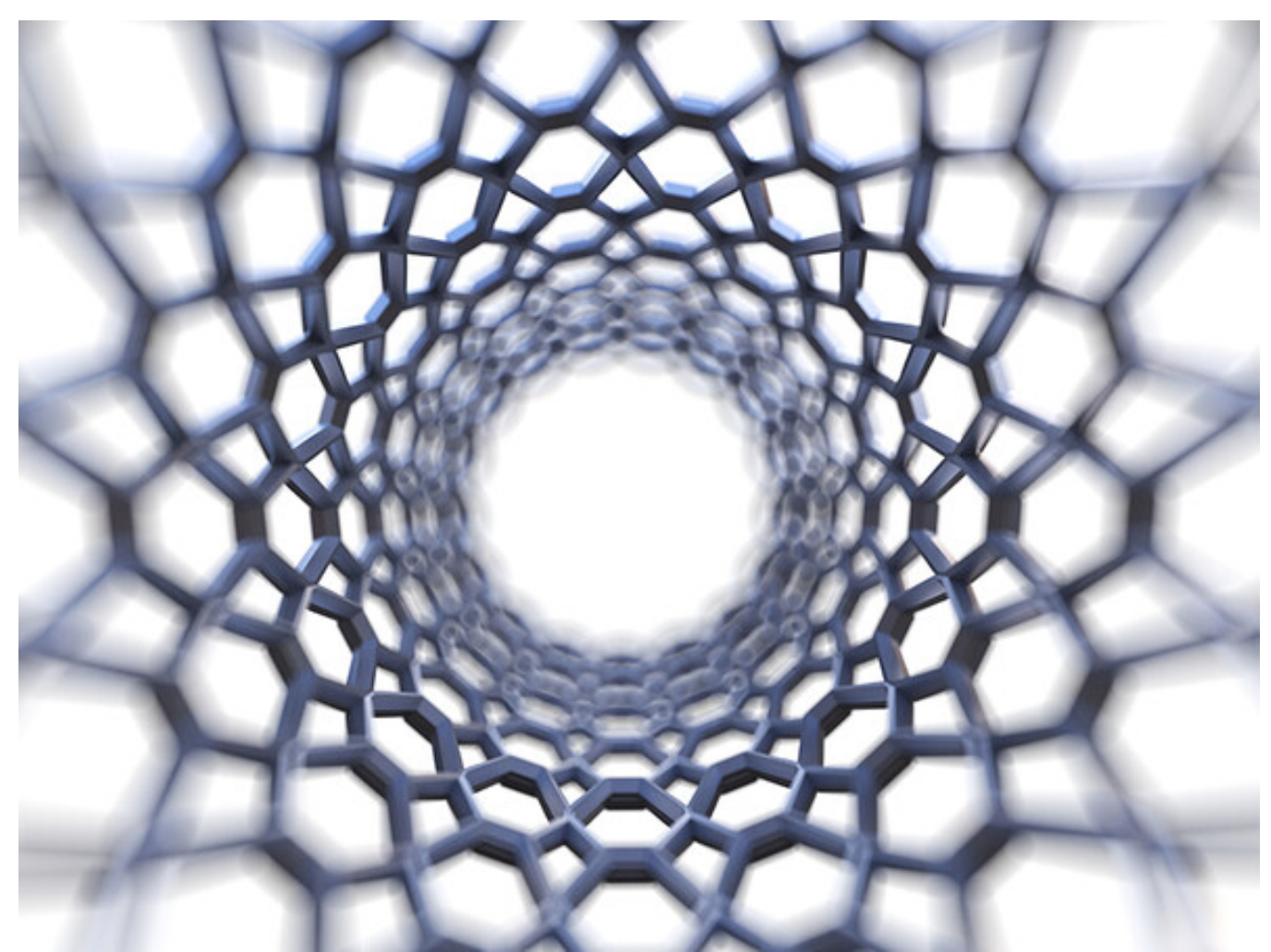

Illustrasjon: Sebastian Kaulitzki / Science Photo Library

Perkutan koronar intervensjon (PCI) har i stor grad erstattet bypassoperasjon som behandling for enkle stenoser i koronarkar, men det er uklart om denne behandlingsformen er like bra som bypassoperasjon også ved trekarssykdom, dvs. ved stenose i alle tre koronarkar samtidig. 
I en multisenterstudie med bidrag fra flere skandinaviske sykehus ble 1500 pasienter med trekarssykdom randomisert til enten PCI-behandling eller bypassoperasjon (1). PCIpasientene ble undersøkt med en trykkmålingsteknikk for å avgjøre hvilke stenoser som var behandlingstrengende. Alle PCI-pasientene fikk innsatt medikamentavgivende stenter.

I løpet av ett år hadde død, hjerteinfarkt, hjerneslag eller behov for ny revaskularisering oppstått hos 10,6 \% av PCI-pasientene, mot 6,9\% av de bypassopererte (hasardratio 1,5; 95 \%$\mathrm{KI}$ 1,1 til 2,2). De som var bypassoperert, fikk imidlertid signifikant oftere større blødninger, arytmi og akutt nyreskade.

- Denne studien bekrefter langt på vei gjeldende retningslinjer og at kirurgi bør være den foretrukne strategien for revaskularisering hos de fleste pasienter med trekarssykdom, sier Alexander Wahba, overlege ved Klinikk for thoraxkirurgi ved St. Olavs hospital og professor ved NTNU.

- Studiens styrke er randomisert design med sammenlikning av moderne PCI-teknikk og moderne teknikk ved bypasskirurgi. Den viktigste innvendingen er at observasjonstiden på ett år er kort. De fleste andre studier har vist at koronarkirurgi er en overlegen behandlingsstrategi først etter flere års oppfølging, sier Wahba.

\section{LITTERATUR}

1. Fearon WF, Zimmermann FM, De Bruyne B et al. Fractional flow reserve-guided PCI as compared with coronary bypass surgery. N Engl J Med 2021;385: NEJMoa2112299. [PubMed][CrossRef]

Publisert: 7. januar 2022. Tidsskr Nor Legeforen. DOI: 10.4045/tidsskr.21.0812

(C) Tidsskrift for Den norske legeforening 2023. Lastet ned fra tidsskriftet.no 26. april 2023. 